\title{
"Det er lidt snyd, er det ik?" \\ En kvalitativ undersøgelse af specialevejledning som forskningspraktik
}

Gitte Wichmann-Hansen ${ }^{1}$, Centre for Educational Development, Aarhus Universitet

Anna Bager-Elsborg, Aarhus Maskinmesterskole

Sune Dueholm Müller, Institut for Virksomhedsledelse, Aarhus Universitet

\begin{abstract}
I denne artikel undersøger vi muligheder og begrænsninger ved en konkret vejledningsmodel, som en specialevejleder har udviklet, hvori studerende tilbydes partnerskab $i$ form af tæt samarbejde og medforfatterskab på en artikel. Vi tager afsæt i litteraturen om "studerende som partnere" og placerer modellen teoretisk inden for denne litteratur som en radikal og elitær udgave af forskningssamarbejde med studerende. Datagrundlaget er longitudinale fokusgruppeinterviews og individuelle interviews med fire specialestuderende. Analysen viser, at de studerende oplever muligheder for et stort læringsudbytte, intens sparring og større jobafklaring. Samtidig viser analysen, at modellen er ressourcekrævende og appellerer til særligt ambitiøse studerende og vejledere.

Artiklen bidrager med nye fund om de indre spændinger mellem styring og selvstændighed, der kan opstå i vejledningen, når vejlederen har flere roller, nemlig rollen som både vejleder, bedømmer og projektleder. Artiklen afsluttes med en række råd til, hvad man bør være opmærksom på i implementeringen af denne type vejledning.
\end{abstract}

\section{Indledning}

Aktiv læring, studenterdeltagelse, engagerende undervisning og lignende plusord har for længst erobret det universitetspædagogiske vokabular. De udtrykker et konstruktivistisk ideal om at fremme studerendes læring gennem meningsfulde, autentiske aktiviteter (Biggs, 2012). Et nyere begreb, som i stigende grad vinder indpas i den universitetspædagogiske litteratur, og som repræsenterer en mere radikal tilgang til aktiv læring, er "studerende som partnere" (Students as partners) (Gravett et al., 2020). Begrebet dækker over mere og andet end at aktivere de studerende gennem undervisningsformer som fx "flipped classroom", "coorporative learning" og "online quizzes". Det indebærer en gennemgribende anden relation mellem studerende og undervisere, idet parterne indgår i en samarbejdsrelation, hvor de studerende forventes at bidrage til enten gennemførelse og udvikling af undervisningen eller til gennemførelse af et konkret forskningsprojekt (Healey et al., 2014). En nyttig og ofte citeret definition af begrebet er "... a collaborative, reciprocal process through which all participants have

\footnotetext{
${ }^{1}$ Kontakt: gwh@au.dk
} 
the opportunity to contribute equally, although not necessarily in the same ways, to curricular or pedagogical conceptualization, decision-making, implementation, investigation, or analysis "(Cook-Sather et al., 2014, s. 67). Definitionen markerer, at det er en proces og ikke et produkt. Det er en måde at arbejde sammen på, hvor studerende tildeles et autentisk ansvar og dermed indgår som aktive medskabere og ressourcer frem for forbrugere af undervisning og forskning (Jung, 2019).

Eksempler på partnerskaber kan være kurser, hvor studerende står for planlægning, gennemførelse eller evaluering af dele af undervisningen (Hill et al., 2019) eller specialeforløb, hvor den studerende indgår i vejlederens igangværende forskningsprojekter, og hvor de efterfølgende sampublicerer en artikel (Jeppsson \& Haglund, 2019).

Ideen om at invitere studerende ind som samarbejdspartnere i forskning har også fået politisk opbakning i det seneste årti. For eksempel har flere danske universiteter i deres strategiske rammekontrakter prioriteret forskellige former for forskningssamarbejde med studerende, bl.a. gennem "studenterinddragelse i forskningsprojekter" (Hansen et al., 2020). Strategien bakkes op i en aktuel rapport fra Uddannelses- og Forskningsministeriet [UFM] om, hvordan universiteterne kan styrke forskningsbaseringen af deres uddannelser bl.a. ved at bruge de specialestuderende som samarbejdspartnere i forskningsprojekter (UFM, 2020, s. 60).

Det er sidstnævnte form for partnerskab, vi sætter fokus på i denne artikel, dvs. et samarbejde mellem specialevejleder og specialestuderende, hvor den studerende tildeles rollen som medforsker og potentielt medforfatter på artikler. Vi har valgt at fokusere på denne form, dels fordi den repræsenterer den mest vidtgående version af at inkludere studerende som partnere i forskningsaktiviteter i form af sampublicering og høje selvstændighedskrav til den studerende (Levy, 2011), og dels fordi litteraturen endnu kun rummer begrænset viden om den dertil knyttede vejledningspraksis (Moore \& Felten, 2018). Litteraturen efterspørger flere konkrete eksempler på, hvordan et samarbejde kan realiseres i specialevejledning (Hansen et al., 2020) samt mere systematisk viden om, hvordan det opleves set fra hhv. vejledernes og de studerendes perspektiv (Healey et al., 2014).

Vi undersøger derfor en konkret model, som en specialevejleder har udviklet og praktiseret de seneste 7 år, hvori studerende tilbydes partnerskab. Undersøgelsen er styret af følgende overordnede forskningsspørgsmål: Hvilke muligheder og begrænsninger rummer en vejledningsmodel, hvor specialestuderende indgår som medforskere og medforfattere i tæt partnerskab med vejlederen?

Først gives et overblik over den spirende forskning om "studerende som partnere". Dernæst præsenteres den konkrete vejledningsmodel. Vejlederens motiver, pædagogiske valg og erfaringer beskrives som en del af modellen, og valget af begrebet om "studerende som partnere" som meningsfuld teoriramme til at forstå den konkrete vejledningspraksis begrundes. Endelig underkastes modellen et kritisk blik, idet den analyseres og diskuteres med afsæt i interviews med de specialestuderende, som har gennemført forløbet.

Vejlederen i den aktuelle case er artiklens sidste-forfatter (Sune Dueholm Müller). Artiklens to andre forfattere har erfaring med universitetspædagogisk udviklingsarbejde og har forestået dataindsamling og analyse.

\section{Specialevejledning som forskningssamarbejde}

Ofte nævnes kandidatspecialet som det uddannelseselement, der bedst muliggør et tæt samarbejde og partnerskab mellem forskere og studerende (UFM, 2020). Forklaringen er, at specialet dels er den lærings- og 
eksamensform, som i særlig grad åbner for studerendes mulighed for at bidrage til vidensproduktion (og ikke kun reproduktion af viden) (Rienecker et al., 2019), dels repræsenterer overgangen fra studerende til professionel og arbejdsmarkedsparat (de Kleijn et al., 2013). På specialeniveau forventes studerende at kunne producere - og ikke kun reproducere - viden og dermed potentielt bidrage til faget med ny viden (Ginn, 2014).

Dette gør studerende til attraktive samarbejdspartnere set fra vejlederens synspunkt, fordi de kan bidrage til og løfte vejlederens egen forskning (Eagan et al., 2011). Studerende kan med deres projekter åbne nye forskningsfelter og stille andre spørgsmål end vejlederen. Dermed kan nye indsigter og erkendelser udvikles og analytiske pointer forfines gennem fælles analysearbejde (Hansen et al., 2020). Særligt kan de studerende som medforskere bidrage til vejlederens forskningsproduktion både $\mathrm{i}$ form af hjælp til dataindsamling og behandling og i særlige tilfælde deltagelse i artikelskrivning (Burks \& Chumchal, 2009).

Set fra de studerendes synspunkt er der også mange gevinster ved at indgå i et partnerskab med forskere. Studier viser, at studerendes højere ordens læring øges markant, når de involveres som aktive og ansvarlige bidragsydere i forskningsaktiviteter (Healey et al., 2014; Osborn \& Karukstis, 2009). Det gælder især udvikling af kompetencer som kritisk tænkning, effektiv kommunikation og løsning af komplekse problemstillinger (Simpson et al., 2019). Andre vigtige gevinster er øget selvtillid og motivation (Wulf-Andersen et al., 2015) forbedret gennemførelse (Kuh, 2008) samt større forståelse for forskningsprocessen (Jung, 2019). Der er imidlertid ikke enighed i litteraturen om, hvorvidt forskningssamarbejdet giver studerende mere lyst til at forfølge en forskningskarriere. Forskningssamarbejde synes at være en vigtig rekrutteringskanal for ph.d.-studerende inden for især STEM-fagene (Christensen \& Tegtmejer, 2015; Laursen et al., 2010), mens det ikke i samme grad er tilfældet i humanistiske fag (Thiry et al., 2012).

Uafhængigt af fagforskelle ser det ud til, at effekten af forskningssamarbejde på studerendes læring og senere valg af forskningskarriere er størst, hvis samarbejdet har været præget af tæt mesterlærevejledning med mulighed for imitation og korrektion (Kuh, 2008; Kuh \& Donnell, 2013). Det er herigennem, at studerendes tiltro til egne kompetencer som forsker opbygges, hvilket kan motivere til at forfølge en forskningskarriere (Shaw et al., 2013; Kiley and Cumming, 2015).

I lyset af at vejledning tilsyneladende spiller en afgørende rolle, er der påfaldende få studier, der undersøger konkrete vejledningspraksisser, og hvilke didaktiske valg samarbejdsformen indebærer (Moore \& Felten, 2018). For at få en mere nuanceret forståelse af mulige styrker og udfordringer i vejledningsmodellen bidrager vi med et konkret eksempel på, hvordan modellen kan udformes.

\section{Beskrivelse af en konkret model for specialevejledning som forskningssamarbejde}

I dette afsnit beskrives den model for specialevejledning, som artiklens sidsteforfatter har udviklet og praktiseret siden 2013 på kandidatuddannelsen i IT, Kommunikation og Organisation (ITKO), på Aarhus Universitet. Modellen benævnes af vejlederen som "Forskningspraktik".

\section{Baggrund og organisering}

Modellen blev oprindeligt udviklet for at give studerende mulighed for at prøve kræfter med et forskningsprojekt, samtidig med at vejleder kunne vurdere deres egnethed som ph.d.-kandidater. Modellen er siden blev udvidet som et tilbud til alle studerende, der har ambitioner og mod på at prøve noget andet og mere end det traditionelle speciale. Hvert år vælger 1-4 studerende ud af årgangens cirka 100 studerende at indgå i modellen. 
Forskningspraktikmodellen tager afsæt i samme fagbeskrivelse som det traditionelle speciale på ITKOuddannelsen, og modellen er dermed underlagt de samme læringsmål og rammevilkår, fx det samme antal ECTS. Modellen er blot en anden måde at udfylde fagbeskrivelsens rammer for specialet på. Forskningspraktik er således ikke en erstatning for specialet eller en "ekstra-curricurlær aktivitet". Den er et tilbud til særligt interesserede studerende, der har lyst og mod på at skrive et speciale, hvor de indgår i et tæt forsknings- og skrivesamarbejde med vejlederen.

Figur 1 viser, hvordan forskningspraktikken adskiller sig fra et traditionelt specialeforløb på væsentlige parametre, som handler om varighed, eksamensproduktet og vejledningsformen, herunder mødeintensitet og feedback.

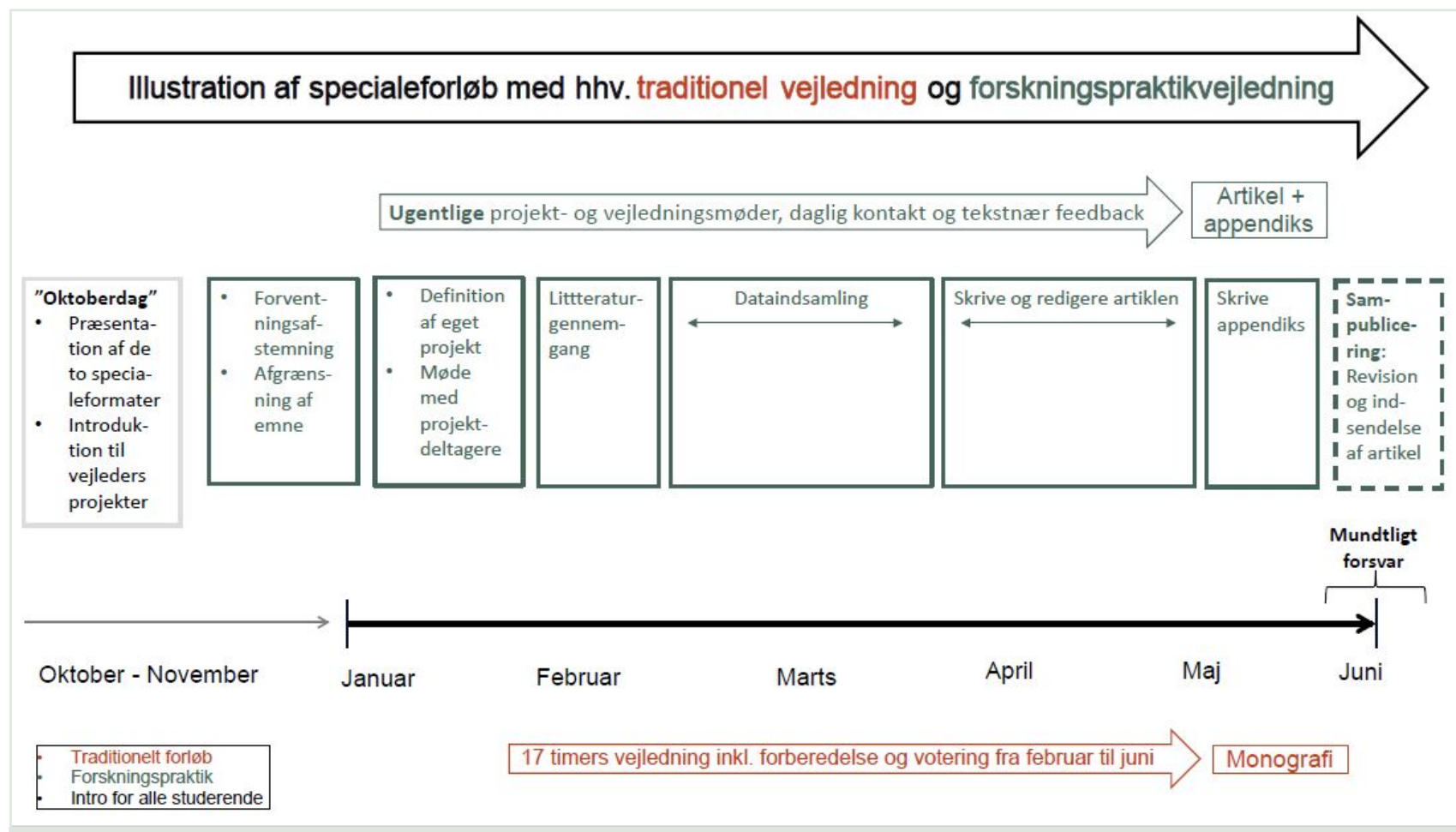

Figur 1: Sammenligning af Forskningspraktik og et traditionelt specialeforløb på uddannelsen

Som det fremgår af Figur 1, starter forløbet principielt allerede i efterårssemestret med den såkaldte "Oktoberdag", hvor alle studerende introduceres til specialet i det kommende forårssemester. Her præsenteres de studerende for muligheden for at tilvælge Forskningspraktik, der italesættes som en mulighed for at indgå i et forskningsmæssigt samarbejde, skrive en videnskabelig artikel og bidrage med ny viden. Beskeden er at "alle kan forske", og at "man ikke nødvendigvis skal være 12-talsstuderende, men skal have ambitioner om at være det". Det understreges, at forskningspraktikken kræver arbejdsflid, men at læringsudbyttet til gengæld er stort qua adgang til vejlederens forskningsnetværk og -data, hyppig vejledning og tekstnær feedback.

De studerende kan enten selv komme med projektidéen eller træde ind $\mathrm{i}$ et eksisterende forskningsprojekt. "Oktoberdagen" bruges som anledning til kort at præsentere igangværende projekter, som studerende har mulighed for at engagere sig i. 


\section{Vejledningsform}

Efter "Oktoberdagen" aftaler interesserede studerende et møde med vejlederen. Formålet er at tale med de studerende om deres interesser og motivation, forklare forskningspraktikmodellen i detaljer og diskutere om ét af de omtalte projekter matcher deres interesser.

På første møde drøftes gensidige forventninger til forløbet og samarbejdsformen, ligesom projektplanen og milepæle drøftes. Behovet for sammen at finde et fokus for de studerendes projekt (og artikel) italesættes. Dette fordrer tæt dialog inden specialestart, således at forskningsspørgsmål og projektplan er på plads ved semesterstart. Det betyder, at vejledningen reelt påbegyndes inden specialestart, og at vejledningen strækker sig over en længere periode (oktober-juni) sammenlignet med det traditionelle speciale (februar-juni). Se Figur 1.

Vejlederen fungerer som forskningsmæssig og fagfaglig sparringspartner, der involveres $\mathrm{i}$ alle aspekter af projektet, herunder design af undersøgelsen (hjælp til litteratur-gennemgangreview, etablering af forskningsdesign, valg af metoder etc.) og opfølgning på undersøgelsen (fastlæggelse af analysestrategi, udarbejdelse af kodeskema, valg af statistiske beregningsmodeller etc.). Vejlederen går så at sige i "maskinrummet" med den studerende og demonstrerer analyser, hjælper med beregninger $\mathrm{mm}$. I den traditionelle specialevejledning er vejlederen langt mindre involveret i projektets detaljer, og vejlederen er kun i begrænset omfang med til at træffe centrale beslutninger om vigtige indholdsmæssige valg i projektet.

I forskningspraktikken afholdes der meget hyppige møder (typisk én eller flere gange ugentligt) med de studerende, og vejleder er tilgængelig på telefon, e-mail og lignende dagligt. Denne hyppige og tætte vejledning står i modsætning til den vejledning, de studerende kan forvente at få i forbindelse med det traditionelle speciale, hvor der er timenormer for vejledning (17 timer i alt inkl. votering).

\section{Samarbejde med eksterne partnere}

Hvis de studerende træder ind $i$ et eksisterende forskningssamarbejde, arrangeres et møde med samarbejdspartnerne i projektet mhp. at forventningsafstemme og brainstorme over artikelidéer. I øvrigt inviteres de studerende til at deltage i relevante projektmøder med samarbejdspartnerne i specialeperioden. Sammen med partnerne drøftes og tilrettelægges undersøgelser under forskningspraktikken.

\section{Eksamensform (Artikel)}

Som det fremgår af Figur 1, er eksamensformen i det traditionelle speciale, at de studerende skriver en monografi, som de forsvarer mundtligt. I Forskningspraktikken skriver de studerende derimod en artikel samt et appendiks (en læringsrapport), og begge dele forsvares mundtligt.

Aftalen er, at efter endt eksamen skal artiklen blive til en videnskabelig publikation, hvor alle optræder som medforfattere. Siden 2013 har mere end 15 studerende været i forskningspraktik, og i alle tilfælde er der kommet en videnskabelig publikation ud af samarbejdet, som enten er udgivet eller i review.

Drøftelsen af "publication outlets" påbegyndes, så snart de studerede har afsluttet litteratursøgningen. De bliver bedt om at overveje: Hvilken akademisk samtale eller diskurs er artiklen en del af? Hvilket forskningsfællesskab interesserer sig for emnet? Hvilke tidsskrifter eller konferencer udgiver artikler om emnet? Når valget er truffet, 
tilskyndes de studerende til at bruge konferencen eller tidsskriftets skabelon samt aflure den arketypiske artikelstruktur.

Når de studerende begynder at skrive på deres artikel, læses tekstudkastene grundigt, og der kommenteres ad flere omgange med detaljeret feedback. Dette er en nødvendig lærings- og kvalitetssikringsaktivitet, da der arbejdes med et nyt format (videnskabelig artikel på engelsk).

Vejleder skriver dog ikke på artiklen i specialeperioden. Dette er for at undgå habilitetsproblemer i forbindelse med forsvar og karaktergivning. Vejleder forpligter sig til gengæld til at overtage ansvaret for artiklen efter forsvaret frem mod publikation.

Foruden artiklen skal de studerende som nævnt vedlægge et appendiks i form af en læringsrapport, hvori de beskriver deres læringsudbytte og arbejdsproces (den faktiske kontra efterrationaliserede proces i videnskabelige artikler). Til formålet udleveres en skabelon indeholdende overskrifter og forslag til emner, som læringsrapporten kan berøre. Denne læringsrapport har typisk et omfang på 25-35 sider. I modsætning til artiklen læses læringsrapporten ikke af vejleder. Begrundelsen er dels, at læringsmålene tilsiger, at de studerende selv skal kunne forklare og forsvare, hvad de har lært, og dermed udvise en høj grad af selvstændighed. Dels er det en uskreven regel i forbindelse med det traditionelle speciale på uddannelsen, at specialevejledere ikke læser eller kommenterer på mere end 30\% af det skriftlige produkt - igen for at værne om de studerendes selvstændighed. Læringsrapporten er dog genstand for samtale og diskussion i forbindelse med vejledningsmøder, hvis de studerende har behov for sparring.

\section{Hvordan kan modellen forstås teoretisk?}

Modellen kan kategoriseres som den variant af partnerskab med studerende, som ifølge Healey et al (2014) hører under betegnelsen forskningssamarbejde, og som forfatterne yderligere kategoriserer som elitemodellen. (Healey et al., 2014, s. 41). Det er en model, hvor få udvalgte studerende tilbydes adgang til et forskningsmiljø i længere tid under tæt vejledning af én eller flere erfarne forskere. Det er typisk et ekstracurriculært tilbud, der kan strække sig fra nogle uger i et laboratorium (Thiry et al., 2012) til et helt år, som det fx kendes fra Forskningsåret på Medicinuddannelsen i Danmark (Christensen \& Tegtmejer, 2015).

Den anden variant er en mainstreaming model, hvor alle studerende i et fag eller på en uddannelse indgår som medforskere, fordi rollen er indtænkt og integreret i studieordningen (Jenkins og Healey, 2012). Selvom Forskningspraktikmodellen er indlejret i en curriculær aktivitet, er der ikke tale om en mainstream-model, da den tilvælges af få studerende.

Inden for elitemodellen kan studerende tildeles forskellige roller. I Bovill et al.'s (2016) terminologi er de studerendes rolle i Forskningspraktikken at være medforskere (co-researchers), idet de indgår i et team af forskere og udfører opgaver, som sikrer fremdrift i et forskningsprojekt, der involverer flere partnere og interessenter, som $\mathrm{fx}$ at styre et projekt og lede et møde. Samarbejdsformen består i hyppige vejledningsmøder, fagfaglig rådgivning, arbejdsfællesskab og sampublicering. Sidstnævnte element, sampublicering, udgør ifølge Levys (2011) teori den mest radikale version af forskningssamarbejde, man kan tilbyde og afkræve studerende, fordi forfatterskab forudsætter en høj grad af selvstændighed, og studerende inddrages i hele forskningsprocessen. 
Med brug af teoretiske begreber fra litteraturen om "studerende som partnere" kan den konkrete vejledningspraksis defineres som:

- Et forskningssamarbejde

- i form af en elitemodel,

- hvor specialestuderende tilbydes rollen som medforskere

- og forventes at bidrage som medforfattere på en artikel sammen med vejlederen.

At modellen teoretisk kan kategoriseres som partnerskab skyldes ikke (kun) den hyppige og tætte vejledning, eller at vejlederen giver adgang til sit miljø og sine data. Det skærende punkt er, at studerende er medforskere, dvs. at de producererforskning, som vejlederen får direkte udbytte af enten i form af en publikation eller i form af hjælp til sine analyser og dataindsamling.

For at forstå vejledningsformen i sin helhed er det yderligere nødvendigt at indplacere den i sin rette fagkontekst, dvs. den samfundsvidenskabelige fagtradition. Forskningssamarbejde med studerende er udbredt i STEM-fagene (Laursen et al., 2010), hvor studerende typisk skriver speciale i tilknytning til eksisterende forskningsprojekter, som styres og defineres af vejlederen (Madsen \& Winsløw, 2009, s. 760). At knytte studerende til eksisterende forskningsprojekter er derimod en atypisk vejledningsform i de samfundsvidenskabelige uddannelser (Magnusson \& Zackariasson, 2019). For det første er der begrænset tradition for at arbejde i forskningsgrupper og at sampublicere inden for disse områder. Becher (1994) skelner imellem urbane og rurale forskningsfelter som et kulturelt karakteristikum, der betegner, hvor "befolket" et forskningsområde er (Becher, 1994, s. 153), og han konkluderer at de samfundsvidenskabelige områder typisk har være tyndere befolket, dvs. med relativt få forskere om brede forskningsfelter.

For det andet er selvstændighed en helt central værdi og et eksplicit læringsmål i de samfundsvidenskabelige specialer (Magnusson \& Zackariasson, 2019). For at værne om de studerendes selvstændighed er mange samfundsvidenskabelige vejledere tilbageholdende med at give råd og input til de studerende (Barnes \& Cheng, 2019; Todd et al., 2006). Tilsvarende tolker de studerende ofte kravet om selvstændighed som ensbetydende med, at de ikke må bede om vejlederens hjælp (Greenbank \& Penketh, 2009; Todd et al., 2004; Malcolm, 2012).

Ovenstående træk ved den samfundsvidenskabelige fagtradition er forklaringen på, at vejlederen tildeler de studerende en rolle i forskningspraktikken, der er mere end blot at være assistenter på hans eller hendes projekter. De forventes at definere problemstillingen selv, de har stor indflydelse på vigtige valg i projektets dataindsamlings- og analysefase, og de er hovedskrivere på artiklen. Men ligesom det kendes fra STEM-fagene, får de studerende i Forskningspraktikmodellen stillet et miljø og tæt sparring til rådighed samt adgang til data. I den forstand kombinerer modellen traditioner fra både "hårde" og "bløde" forskningstraditioner (Biglan, 1973).

Efter at have udfoldet modellen og indplaceret den i relevant litteratur vender vi os nu mod at undersøge modellen empirisk set fra studerendes synspunkt.

\section{Metode}

Undersøgelsen er designet som casestudie, da formålet er at opnå detaljeret og praksisbaseret viden om et afgrænset fænomen (Ramian, 2012); i dette tilfælde muligheder og begrænsninger ved en konkret vejledningspraksis. Casen er strategisk valgt som en unik case (Yin, 2009), idet casen repræsenterer en radikal variant af vejledning som forskningssamarbejde ifølge dominerende teorier og studier på området (se fx Levy, 
2011). Casens analyseenhed er den konkrete specialevejledningsmodel, som vi har beskrevet ovenfor, og som vi undersøger empirisk gennem kvalitative interviews med de fire specialestuderende, som senest indgik $i$ et forskningssamarbejde med vejlederen. Alle fire studerende er kvinder.

\section{Empiri - kvalitative interviews}

Interviewene blev gennemført longitudinalt hen over forårssemestret 2020, fordelt med et fokusgruppeinterview i starten af semestret (januar) og midtvejs (april). Efter afsluttet eksamen i slutningen af semestret (juni) interviewede vi igen de fire studerende, men denne gang individuelt grundet koordinationsvanskeligheder givet de studerendes liv som dimittender. Fokusgruppeformatet valgte vi ud fra et ønske om at etablere et socialt rum, hvor de studerende kunne hjælpe hinanden med at associere og formulere tanker om en proces, der ikke nødvendigvis var nem at artikulere (Almutrafi, 2019).

Vi valgte et longitudinalt design for at kunne 1) følge en mulig udvikling over tid, da samarbejdsrelationer i vejledning ikke er statiske fænomener (Boehe, 2016), og 2) indfange de studerendes oprindelige motivation og forventninger til samarbejdet i starten og ikke kun deres oplevelser set retrospektivt i lyset af karakter og udbytte (Lee \& McKenzie, 2011). Grundet Covid-19 blev fokusgruppeinterview 2 og de efterfølgende fire individuelle interviews afviklet online via Zoom. Alle interviews blev gennemført ved brug af en semistruktureret guide tilpasset tidspunktet i forløbet (start, midtvejs, slut). Se Tabel 1.

1.

Fokusgruppeinterview

Motivation

Forventninger

Forventninger

Sam

Sammenligning med traditionelt speciale ${ }^{i}$
2.

Fokusgruppeinterview

Status

Forventninger

Udbytte
3.

Individuelle interviews

Status

Forventninger

Udbytte

Sammenligning med traditionelt speciale

Anbefalinger

Tabel 1: De semistrukturerede interviewguides

Alle fire studerende gav skriftligt samtykke til deltagelse i forskningsprojektet og offentliggørelse af deres udsagn i anonymiseret form. Fokusgruppeinterviewene varede i gennemsnit 1 time, mens de individuelle $\mathrm{i}$ gennemsnit varede $1 / 2$ time. Interviewene blev transskriberet og behandlet i programmet Nvivo20.

\section{Kodning og analysestrategi}

Efter gennemlæsning af de transskriberede interviews foretog vi en åben og induktiv kodning, hvor der blev dannet fire hovedkoder, som udgjorde de overordnede temaer i interviewene (se Tabel 2). De longitudinale data 
muliggjorde en skelnen mellem de studerendes forventninger og deres retrospektive vurderinger af det oplevede. Derfor fremkom underkoderne "Forventet" og "Oplevet". Herefter foretog vi en ny åben og induktiv kodning inden for hver underkode, som resulterede i 27 under-underkoder.

Analysen af de kodede data fulgte det princip, som Miles et al. (2014) kalder "compare and contrast": Vi sammenlignede og modstillede data, der var kodet som hhv. forventninger og reelle oplevelser, da studiet sigtede mod at afdække styrker og udfordringer i den konkrete vejledningsmodel og dermed mulige dilemmaer og interne spændinger i praksissen.

\begin{tabular}{|c|c|c|}
\hline Temaer & Underkoder & Under-underkoder \\
\hline \multirow[t]{2}{*}{ 1. Udbytte } & Forventet & $\begin{array}{l}\text { 1. Jobafklaring: om man vil tage en ph.d. bagefter } \\
\text { 2. Bedre karrieremuligheder }\end{array}$ \\
\hline & Oplevet & $\begin{array}{l}\text { 3. Jobafklaring: ikke ph.d. } \\
\text { 4. Indsigt i forskningsarbejdet } \\
\text { 5. Ekspertviden/specialisering/fordybelse } \\
\text { 6. Projektledelse og teamsamarbejde } \\
\text { 7. Personligt: Fleksibilitet og selvtillid }\end{array}$ \\
\hline \multirow[t]{2}{*}{ 2. Krav } & Forventet & $\begin{array}{l}\text { 8. Ambitiøs } \\
\text { 9. Hårdtarbejdende } \\
\text { 10. Selvstændig } \\
\text { 11. Rygter om det nemme vs. svære speciale }\end{array}$ \\
\hline & Oplevet & $\begin{array}{l}\text { 12. Ambitiøs } \\
\text { 13. Hårdtarbejdende } \\
\text { 14. Selvdisciplin } \\
\text { 15. At blive udfordret } \\
\text { 16. At tage imod kritik fra vejleder } \\
\text { 17. At kunne sige fra og stå fast over for vejleder; en } \\
\text { bestemt støbning }\end{array}$ \\
\hline \multirow[t]{2}{*}{ 3. Vejledning } & Forventet & $\begin{array}{l}\text { 18. Sparringspartner - at man ikke er alene } \\
\text { 19. Stor sikkerhed } i \text {, at vejleder tjekker, inden man } \\
\text { afleverer }\end{array}$ \\
\hline & Oplevet & $\begin{array}{l}\text { 20. Trygt: nurset } \\
\text { 21. Krævende: skubber, presser } \\
\text { 22. Snyd }\end{array}$ \\
\hline
\end{tabular}


4. Artikel

23. Kontrast mellem to formater

24. Eksamen: skævvridning

25. Håndgribeligt produkt

26. Svær genre

27. Råd: startkasse

Tabel 2: Slutkodeliste (kursiv angiver respondenternes egne ord)

\section{Resultater}

De fire kvindelige studerende omtales her i anonymiseret form som Astrid, Berit, Charlotte og Dorte. To af dem skrev speciale sammen som par, mens de andre skrev hver for sig. Én af dem kom med sit eget projekt, mens de andre indgik i vejlederens igangværende forskningsprojekter.

\section{Udbytte}

Når de studerende talte om udbyttet af at være i forskningspraktik, var der især én ting, som optog dem. De fortalte samstemmende, at de havde fået nogle praktiske erfaringer med sig, som de ikke mente, et traditionelt speciale ville give. De brugte oftest ordet "projektleder" til at sammenfatte de kompetencer, de havde erhvervet i form af teamsamarbejde med erfarne praktikere i en virksomhed eller forskere på universitetet og i form af mødeledelse, projektplanlægning og tidsstyring. Med kompetencerne fulgte stolthed og øget selvtillid, i takt med at statusforskellen mellem dem og samarbejdspartnerne blev mindre. Følgende citat udtrykker dette, hvori Charlotte fortæller om samarbejdet med en gruppe overlæger:

Det er jo nogle tunge drenge, vi har siddet med. Altså, det er nogle, jeg har stor respekt for, og nogle, der virkelig har deres faglighed med sig. Og de er begyndt at have respekt for os, og hvad vi gerne vil, og hvad vi kan, så det er jo et vildt selvtillidsboost. (3. Individuelle interviews, Charlotte)

De praktiske erfaringer blev også omtalt som modsætning til den teori, de havde lært på universitetet. Resultatet var stor tilfredsstillelse ved at have lært at håndtere autentiske og komplekse situationer, som man ikke kan "læse sig til i en bog". Det havde gjort dem mere fleksible, analytiske, systematiske og selvsikre, og de mente, det var nyttige kompetencer, som de kunne bruge efterfølgende på et arbejdsmarked - og især som projektledere. Praktikken havde således motiveret dem til at komme ud på arbejdsmarkedet efter endt speciale og prøve kræfter med deres nye specialiserede viden og projektledelseskompetencer, som var en central del af uddannelsens faglighed.

Forskningsprocessen viste sig at være mere uforudsigelig og iterativ end forventet, og det havde både ledt til frustrerende og stressende perioder. Af samme grund havde det ikke givet dem lyst til at fortsætte $i$ en forskerkarriere. Mens de i det første interview udtrykte en forventning om, at forskningspraktikken kunne være en mulig vej ind $\mathrm{i}$ en ph.d. bagefter, konkluderede de i sidste interview, at ideen om en ph.d. ikke tiltalte dem længere. 
Krav

Der var et stort sammenfald mellem de studerendes forventninger til rollen som forskningspraktikant, og hvad de reelt oplevede. I første interview nævnte alle fire, at forskningspraktikken er et ambitiøst projekt, i den forstand at man som studerende skal være indstillet på at arbejde hårdt og flere timer end i forbindelse med et normalt speciale. Ud over flid og arbejdsindsats anså de det som en fordel at kunne tænke selvstændigt og have et "relativt højt niveau". I andet og tredje interview havde de studerende gjort sig erfaringer med forløbet, som bekræftede forventningerne, men som også tilføjede et krav. Kravet handlede om at have selvindsigt - at vide, hvad man vil; at kunne tage styringen selv og kunne sige fra. Det særlige ved kravet var, at det både blev formuleret som en kompetence, man lærte undervejs i forløbet, og som et iboende karaktertræk, dvs. noget man ideelt skulle besidde, inden man gik i praktik. Oplevelsen af at skulle tage ansvar, blive testet og presset fra mange sider og forsøge at imødekomme ambitiøse samarbejdspartnere gjorde det nødvendigt for dem alle på et tidspunkt at markere, hvor langt de ville og kunne være med. For eksempel fortalte Berit om, hvordan hun flere gange måtte "tage en dyb indånding" og sige til sig selv "jeg er også voksen" for ikke at gå i gang med de "30 projektideer", som hendes forskningsgruppe kom med, og som hun ikke havde tid til. Samtidig taler både hun og de andre om det som et personlighedsspørgsmål; som en type man enten er eller ikke er, hvilket fremgår af nedenstående citater:

Man skal være af en bestemt støbning for at kunne klare det. [...] Man skal også være i stand til at kunne genkende, hvornår man ligesom har nået et punkt, hvor der ikke er mere at give af i elastikken."

(3. Individuelle interviews, Berit)

Hvis man er sådan en studerende, der har behov for, at du fär en lektionsplan og fär at vide: "I den her uge foregår det her, næste uge gor du det her, det er en lige vej, og så ender vi hér", så er det måske ikke det, man skal. Det kræver en fleksibilitet i mindsettet. (2. fokusgruppeinterview, Astrid)

Analysen og citaterne viser, at der således var en dobbelthed i de studerendes forståelse af praktikken som et forløb, hvor de på den ene side fik trænet eller "støbt" bestemte kompetencer, men hvor det på den anden side var en fordel at være af en bestemt "støbning" fra starten for at klare praktikken i form af fleksibilitet, selvindsigt, hårdt arbejde, ambitioner og evnen og viljen til at tage ansvar.

\section{Vejledning}

Det var et centralt fund i analysen (på tværs af hovedtema 2 og 3), at vejledningen rummede et dilemma for de studerende, som kan betegnes støtte versus se/vstændighed. På den side værdsatte de studerende hyppig og omfattende feedback, som de især fik af vejlederen, men også af samarbejdspartnere i projektgruppen. Alle fire studerende gik ind i samarbejdet med en forventning om, at vejlederen ville udgøre en tryg støtte og en slags garant for høj kvalitet i det endelige produkt. Forventningen blev til fulde opfyldt, idet de oplevede, at vejlederen altid var tilgængelig, svarede hurtigt, returnerede artikeludkast med fyldige detailkommentarer, hjalp med at udarbejde en tidsplan og var lydhør, når de havde behov for at dele frustrationer over uforudsete problemer. Både i forhold til vejledningens omfang og rettidighed nævner de gentagne gange, at det er langt ud over, hvad de mener kendetegner et traditionelt speciale:

Hvis jeg skal sammenligne med dem, jeg læser med, der skriver et almindeligt speciale, så føler jeg mig meget nurset igennem processen. Jeg kan huske en dag, hvor jeg bare sad over noget metode og tænkte: "Det fatter jeg ikke, det her, det er megafrustrerende, hvilken vej jeg skal gå". Og så skrev 
jeg til [vejleders navn]: "Hej. Jeg bøvler lige med det her. Har du tid?". Og så skrev han: "Du kan ringe om 2 timer". Altså det er sådan en svartid, som jeg generelt har oplevet. [...] "Og hold da op, altså. Det er virkelig meget feedback, man får. Og det sætter jeg simpelthen så meget pris på. Men jeg synes også, det er meget, ift. jeg ved, hvor lidt andre specialestuderende kan få. (2. fokusgruppeinterview, Astrid)

På den anden side bekymrede de sig om, hvorvidt al hjælpen gjorde, at deres arbejde blev anset for mindre selvstændigt end et traditionelt speciale. Analysen viser, at de studerendes brug af begrebet "snyd" indfangede essensen af dilemmaet. De overvejede gentagne gange og igennem alle interviews, om det var snyd, at man $\mathrm{i}$ forskningspraktikken fik mere vejledning end andre medstuderende. Især var de optaget af, at artikelteksten blev læst og gennemrettet og dermed til en vis grad forhåndsgodkendt inden eksamen. De brugte ord som at blive "nurset", "båret igennem", "få nem adgang" og "få det foræret" til at beskrive den potentielle risiko, der ligger i, at hyppig og grundig vejledning ville så tvivl om, hvorvidt arbejdet kunne krediteres den studerende.

Altså, nu siger jeg bare lige noget, og det er slet ikke sikkert, I andre er enige. Men jeg kan faktisk godt synes, at det er lidt snyd, at vi fär så meget vejledning. Øhm...også i forhold til det endelige produkt, at det bliver rettet så meget. Det bliver meget meget bedre. Jeg bliver jo virkelig hjulpet meget $i$ forhold til dem, der næsten ingen vejledning fär. Så derfor kan jeg godt tænke: "Det er lidt snyd, er det ik?" (2. fokusgruppeinterview, Astrid)

I andet fokusgruppeinterview (citeret ovenfor) blev Astrid bakket op af de andre studerende $\mathrm{i}$ hendes overvejelser. Overvejelserne var blandt andet provokeret af medstuderendes antydninger af, at forskningspraktikspecialet var snyd, hvilket var en bekymring, som allerede kom frem i første fokusgruppeinterview:

Dorte: Der er nogle fra mit studie, der har været sådan: "Nu skal du skrive forskningspraktik. Fär du så ikke bare at vide, hvad du skal gøre?"

Berit: Ja, det har lidt været sådan lidt: "Du har valgt den nemme pakkeløsning"

Astrid: "Det korte speciale" - er der også nogle, der har sagt.

Når de studerende alligevel i tredje og sidste interview - efter endt forløb - konkluderede, at det ikke var snyd, og at specialet ikke kunne betegnes som en "nem løsning", skyldtes det, at de havde erfaret, at vejlederen og den samlede proces stillede meget høje krav til dem og tildelte dem en høj grad af medbestemmelse. Vi udfolder dette fund nedenfor.

I starten af forløbet udtrykte de studerende en klar forventning om, at vejlederen ville udgøre den trygge ramme; den støtte, de kunne læne sig op ad, hvis tingene blev svære, og at det var vejlederen, som ville "tjekke," at det færdige produkt levede op til høje standarder. Muligheden for at have en sparringspartner og ikke stå helt alene i processen var en vigtig grund til at vælge modellen. Efter endt forløb var de blevet bekræftet i dette, men de havde samtidig erfaret, at vejlederen ikke kun var en støtte, men også var krævende. Meget tekstfeedback og mange detailrettelser var ikke kun et udtryk for nursing, men også udtryk for høje ambitioner og et krav om, at de havde vilje og evne til at indarbejde kommentarerne, hvilket indfanges i følgende citat: 
Du skal være klar over, at forste gang og anden gang, og tredje gang, du afleverer et udkast, dér fär du et sted mellem 100 og 500 kommentarer tilbage, og det er kun for at gøre det bedre. Altsă, det var meget overvældende, det der med at modtage et Word-dokument i starten, hvor der nærmest ikke er noget rent tekst. Det er kun sådan nogle kommentarbobler. Det er det, jeg mener med, at han er i stand til at presse en; at han er i stand til ligesom at sige jamen "du har gjort det godt, men jeg ved også godt, at du kan gøre det bedre". (Individuelt interview, Berit)

Hyppig og instruktiv vejledning om forskningsdesign, metode og analyse viste sig også at rumme et element af både støtte og hårdt pres. Citatet nedenfor er valgt, fordi det eksemplificerer, hvordan de studerende oplevede, at vejlederen var ambitiøs på deres vegne:

Inden projektet startede, havde jeg sådan et håb om at kunne få i hvert fald 4 virksomheder med, men jeg er faktisk lykkedes med at få data fra 13 virksomheder. Altså, jeg vil sige, det har været lidt grænseoverskridende, hvis jeg sådan har sagt, at "jeg har ikke lige kunnet fä fat i den her [virksomhed]", og så har [vejleders navn] været sådan "prov igen" (griner). Men det bekræfter jo bare, at det er fedt, at der er én, der sådan presser på og siger "jamen - jo mere data, du kan få puttet på, jo bedre". Han har været dygtig til at presse mig, når han fornemmede, at jeg var ved at springe over, hvor gærdet var lavest. (3. individuelle interviews, Astrid)

Det er således i krydspresset fra de høje krav, at forklaringen skal findes på, hvorfor de studerende ikke anså praktikmodellen som "det nemme" speciale. Som mod-udtryk til "nemt" talte de bl.a. om at være "på udebane", "på dybt vand" og "gå uden for rammerne". At knokle, udholde frustrationer, lære at sige fra, satse højt og ambitiøst og projektlede et team af erfarne forskere og praktikere var for dem alt sammen med til at retfærdiggøre en høj grad af vejlederstøtte og feedback.

Det var dog ikke kun det høje pres, der legitimerede den omfattende vejledning. Det høje læringsudbytte blev også brugt som argument for mere vejledning end i forbindelse med et traditionelt speciale.

Altså normalt, når man afleverer en opgave, selvom man har sparring med sin vejleder, uanset hvor meget man har, så ved man ikke helt, hvad det er, man går ind til eksamen med, men vi fär simpelthen den der feedback med det samme, og vi når at lære af den, og så prøver vi igen, og så fär vi feedback en gang mere, sådan at vi faktisk kan lære af vores fejl hele tiden. (3. individuelle interviews, Charlotte)

Hovedpointen genfindes i samtlige interviews med de studerende. Når de kiggede tilbage på processen og sammenlignede med traditionelle specialer, konkluderede de, at mange, detaljerede og løbende tekstrettelser var en essentiel kilde til læring.

\section{Artikel}

I det sidste afsluttende interview var de studerende fokuserede på deres oplevelser med at skrive artikel. De talte om artiklen som et håndgribeligt produkt, som de var meget stolte af, og som de mente var karrierefremmende sammenlignet med et normalt speciale. Nogle havde allerede oplevet, at en artikel gav respekt i virksomheder, hvor de havde søgt arbejde, og at det blev set som et kvalitetsstempel, at arbejdet var publicerbart. Mens det færdige produkt blev omtalt som noget, man stolt kunne vise frem, blev processen med at skrive artiklen omtalt som krævende og famlende. Det var en ny og svær genre at skulle lære på kort tid, fordi den dels var på engelsk, dels var et komprimeret format med få ord til rådighed. Selvom vejlederen havde givet 
dem en artikel til inspiration midtvejs, efterlyste de en "startpakke" tidligt i specialeforløbet med flere eksempler på artikler og en opsummering af de vigtigste genretræk.

Endelig afslørede analysen et centralt dilemma i forhold til artikelformatet. For de studerende fremstod de to formater, hhv. artiklen og læringsrapporten, modsætningsfyldte. Artiklen repræsenterede et stramt format med veldefinerede genrekriterier, som var gennemarbejdet og kvalitetssikret af vejlederen. I kontrast hertil stod læringsrapporten som et personligt og reflekterende papir uden klare genrekrav, men med plads til at udfolde procesmæssige overvejelser og faglige synspunkter. Når de talte om værdien af at skrive en læringsrapport, var vandene delte. De studerende, der skrev sammen og oplevede udfordringer i forløbet, talte om rapporten som en god anledning til at dokumentere alle trinene $\mathrm{i}$ forskningsprocessen og vende frustrationerne til noget positivt og lærerigt. De andre havde derimod oplevet det som kedeligt og svært at skrive rapporten pga. manglende genrekrav og forventninger.

Jeg vil sige, det sværeste eller det kedeligste, var arbejdet med det der appendiks, vi skulle lave, den der projektrapport. Man kommer lige fra at have arbejdet med den der artikel, der [var] virkeligt krævende - altså man skulle virkelig klemme hver eneste dråbe ud af sig selv - og så til det der appendiks, hvor det var sådan: "Jamen, skriv hvad du har lært". Øhhh...altså, det var lidt svært, men på den anden side relativt nemt: Hvis der ikke er noget krav, så må jeg jo bare prove mig frem og så se, hvordan det går. (3. individuelle interviews, Astrid)

Selvom de studerende var uenige om værdien af at skrive læringsrapporten, var de enige om, at de modsætningsfyldte formater gav en oplevelse af uklare bedømmelseskrav til den mundtlige eksamen. De oplevede, at rapporten fyldte det hele til den mundtlige eksamen, mens de havde brugt mest tid og flest kræfter på artiklen. Det gjorde det uklart for dem, hvad de egentlig blev bedømt på, og om de havde forberedt sig forkert til eksamen ved at være skarpe på artiklen og mindre fokuserede på appendikset.

\section{Diskussion}

Formålet med undersøgelsen var at beskrive og analysere en særlig model for specialevejledning, hvor studerende indgår som partnere i produktion af forskning, og kortlægge de muligheder og begrænsninger, modellen rummer. Inden vi svarer på forskningsspørgsmålet om muligheder og begrænsninger, diskuterer vi nogle af de indre spændinger og dilemmaer, analysen afdækkede, fordi de udgør et vigtigt bidrag til den eksisterende litteratur om forskningssamarbejde med specialestuderende.

Citatet "Det er lidt snyd, er det ik?" indgår i artiklens titel, fordi det viste sig at være ikonisk og betydningsmættet for studiets hovedfund. De studerende kredsede flere gange om spørgsmålet om vilkårene for specialeskrivning sammenlignet med deres medstuderende. Deres vejleder var til rådighed med opfølgning, vejledning og feedback i en grad ud over, hvad der er til rådighed i traditionel specialevejledning. De var bevidste om, at vejlederen havde en interesse $i$, at det blev godt, fordi han også selv skulle kunne stå inde for produktet (artiklen). Det skabte bekymring undervejs i forløbet, om deres arbejde kunne betegnes som selvstændigt, og om andre kunne anklage dem for snyd. Dette fund er ikke i sig selv nyt, da det udtrykker en generel bekymring, som er velbeskrevet i ph.d.-vejledningslitteraturen, og som handler om, at vejlederstyring og -kontrol kan koste på de studerendes selvstændighed (Bastalich, 2015). Studier, der har undersøgt forskningssamarbejde med specialestuderende, adresserer samme bekymring og finder samstemmende, at modellen har et indbygget vejledningsdilemma, som Hansen et al. (2020) opsummerer som "investorrationalet versus læringsrationalet". Dilemmaet består i, at vejlederen på den ene side har en naturlig egeninteresse $\mathrm{i}$ afkastet af sin investering $\mathrm{i}$ 
form af hjælp til forsknings- og artikelproduktion. På den anden side må vejlederen varetage den studerendes læringsinteresse, dvs. den studerendes behov for at dygtiggøre sig og udvikle kompetencerne i fagets målbeskrivelse. Denne potentielle interessekonflikt genfandt vi i vores datamateriale, men den viste sig at være mere nuanceret end som så. Det nye, som vores studie bidrager med, er, at de studerende efter endt forløb konkluderede, at hyppig, omfattende vejledning og korrigerende feedback gik hånd $\mathrm{i}$ hånd med selvstændighed. Det stod ikke i modsætning til selvstændighed, men var nærmere en forudsætning. Forklaringen er ifølge vores analyse, at når studerende inviteres ind som partnere ændres deres rolle fra at være studerende til at være medforskere, fra solo-skrivere til medforfattere, fra forbruger af viden til bidragsydere i vejlederens forskningsproduktion. Rolleskiftet stiller høje krav til autenticitet, medbestemmelse og symmetri i samarbejdsrelationen. De forventes at levere det ypperste inden for korte deadlines, navigere i komplekse samarbejder med mange interessenter, kunne udholde kritik og inkorporere det i deres arbejde og lære at markere, hvor deres egne grænser går. For at studerende kan honorere disse høje krav, fordrer det, at vejlederen investerer tid og kræfter i at give rettidig og omfattende feedback, støtte studerende i svære beslutninger og give sparring på stort og småt. Høje krav og stort læringsudbytte retfærdiggør således omfattende vejlederstøtte og -feedback. Det er denne gensidige kontrakt om tryghed, interessefællesskab og professionalitet i forskningssamarbejdet, der er kimen til at kunne ophæve vejledningens indbyggede didaktiske konflikt mellem styring og selvstændighed og dermed afmontere bekymringen om snyd. Formentlig vil vejledningsmodellen falde fra hinanden eller risikere at ende i en "slave-model" (Hansen et al., 2020), hvis studerende mødes af høje krav om at levere til vejlederens forskningsproduktion uden tilstrækkelig støtte, symmetri i relationen eller opbakning til at bevæge sig ud på dybt vand og begå fejl undervejs.

Når vi så tydeligt genfinder det klassiske dilemma fra ph.d.-vejledningen mellem hands-on-vejledning og ejerskab (Deuchar, 2008) i denne specialemodel, er forklaringen sandsynligvis, at samarbejdet kommer til at ligne en komprimeret ph.d.-vejledningssituation. Vejlederen har investeret meget, den studerende bidrager til forskningsproduktionen, og de sampublicerer artikler. Det vidner om værdien, men også udfordringerne $\mathrm{i}$ at gøre kandidatstuderende til partnere. Distancen og asymmetrien mellem studerende og underviser reduceres, og de studerende transformeres fra at være forbrugere til at være ressourcer (Gravett et al., 2020). Men i denne model kompliceres rollerne af, at vejledning og bedømmelse på specialeniveau udføres af samme person, der har en personlig forskningsmæssig egeninteresse. Senest har et svensk studie peget på en særlig etisk konflikt i sampublicering med specialestuderende, idet vejlederens egeninteresser i artikelskrivningen potentielt kan gøre vejlederen inhabil som bedømmer af det færdige speciale, selvom artiklen først færdigskrives efter karaktergivning (Jeppsson \& Haglund, 2020). Vejlederen fra dette studie har forsøgt at imødegå denne etiske udfordring i sampublicering ved at tilføje en læringsrapport til afleveringsformatet, som han ikke læser forud for eksamen. Men som analysen viser, gav det anledning til nye dilemmaer. De studerende oplevede, at der var uklare bedømmelseskrav til læringsrapporten, og at de to formater (artiklen og læringsrapporten) var meget modsætningsfyldte.

Betyder det, at forskningssamarbejde med specialestuderende rummer for mange uløselige dilemmaer? Baseret på vores fund og den eksisterende forskning vil vi svare nej, men det kræver en særlig tydelig rolleafklaring samt klart beskrevne rammer for bedømmelsen.

Behovet for forventningsafstemning tidligt og løbende er ligesom i al anden vejledning centralt (Rienecker et al., 2019), men sættes på spidsen i denne model, som især kræver forventningsafstemning

- om og med de mange interessenter

- om den fælles afhængighed af delleverancer 
- om delt ejerskab til outputtet (artiklen) og

- om den begrænsede valgfrihed for projektets ambitionsniveau.

For at reducere usikkerheden om modellens legitimitet og potentielle rygte som "den nemme løsning" (snyd), er der brug for, at den ikke kun eksisterer som individuel vejlederpraksis, men institutionaliseres, fx gennem beskrivelse i studieordningen som et muligt eksamensformat. Det er en generel anbefaling i litteraturen om studerende som partnere, at de underliggende værdier i tilgangen må anerkendes som en strategi af institutionen, hvad enten det er på fagniveau, institutniveau eller fakultetsniveau (Sprocken-Smidt et al., 2013; Gravett et al., 2020). Når praksisser skrives ind i studieordninger, øger det samtidig sandsynligheden for, at eksamens- og undervisningsformer alignes, og bedømmelseskriterier bliver (mere) transparente.

\section{Styrker og svagheder ved designet}

Styrken ved dette studie er, at vi inkluderede de studerende, der senest indgik i forskningspraktikken, og som alle valgte at deltage. $\mathrm{Vi}$ har dermed fået hele populationen af forskningspraktikanter i alle tænkelige skrivekonstellationer med (alene, sammen, med eget projekt og med vejleders projekt). Da vi fandt, at de særlige konstellationer ikke havde afgørende betydning for udbyttet, står de centrale fund om selvstændighed og vejlederstyring ekstra tydeligt frem. Endelig har vi fulgt de studerende gennem hele processen, hvorfor vi har fået deres "nu og her"-oplevelser og ikke kun forventninger eller efterrationaliseringer. En svaghed ved studiet er, at populationen kun bestod af fire studerende og én vejleder. Desuden afdækker casen kun én bestemt faglig kontekst, og modellen for vejledning er knyttet tæt til den specifikke vejleder. Det betyder, at man i udgangspunktet ikke kan generalisere på tværs af tid og kontekster. Resultaterne peger dog på, at modellen kan være interessant for andre "bløde" fagligheder inden for samfundsvidenskab og humaniora, hvor der ikke hidtil har været en stærk tradition for at knytte specialestuderende til vejlederens forskning. Samtidig peger resultaterne på, at ikke alle bløde fag vil kunne adoptere modellen lige nemt. Modellen egner sig primært til fag, hvor der publiceres forskningsartikler (i modsætning til bøger eller antologier), og hvor der samarbejdes om forskningsopgaver (i modsætning til at arbejde alene). Biglan (1973) peger på, at traditionen for at samarbejde om artikelpublikation findes $i$ hårde fag som fx fysik og kemi, men også i bløde fag, som er anvendelsesorienterede ("applied soft"), fx inden for ledelse og en række samfundsvidenskaber (Biglan, 1973, s. 208).

\section{Konklusion}

Vores studie bekræfter den eksisterende litteratur om studerende som partnere, der viser at både studerende og vejledere rapporterer en række gevinster ved at indgå i tæt samarbejde som medforskere i en fælles forskningsproduktion. Ifølge de interviewede specialestuderende giver forskningspraktikken mulighed for autentisk læring, jobafklaring og udvikling af arbejdsmarkedsrelevante kompetencer, dyb indsigt i forskningsprocesser, udvikling af højt specialiseret viden, fortrolighed med artikelgenren og en accelereret læreproces med intensiv og hyppig feedback. Forløbet leder ikke umiddelbart til et ønske om en forskningskarriere, men de studerendes samarbejde med eksterne parter og vejleder giver dem mulighed for at afprøve deres universitetserhvervede kompetencer "ude i virkeligheden" og omsætte dem til en artikel, der vækker beundring og anerkendelse uden for universitetets mure. Selvom vejlederen oprindeligt har tænkt praktikmodellen som en rekrutteringskanal for fremtidige ph.d.-studerende, har den nærmere vist sig at fungere som en god "udslusning" fra universitetet med mulighed for at erhverve projektledererfaringer. Dette fund skal ses $\mathrm{i}$ lyset af, at undersøgelsen er foretaget på en samfundsvidenskabelig uddannelse, som bl.a. uddanner 
kandidater til projektlederstillinger i virksomheder. Det er muligt, at en tilsvarende model for forskningspraktik vil være mere forskningskarrierefremmende i såkaldt hårde fagfelter eller styrke andre typer kompetencer af relevans inden for andre fagområder.

I lighed med eksisterende forskning viser vores studie, at der er klare fordele for vejlederen. Det øger vejlederens forskningsproduktion markant, idet samtlige 15 gennemløb over de sidste 7 år har ført til publicerede artikler.

Der er dog også begrænsninger ved forskningssamarbejder med studerende, hvilket få studier tidligere har beskæftiget sig med (Bovill et al., 2016). Vores studie viser, at det er krævende at praktisere forskningspraktikmodellen, da den er ressourcetung for både studerende og vejleder. Den er ikke nødvendigvis egnet til alle. Det er en elitemodel - ikke for de dygtigste studerende, men for de ambitiøse. Man skal være af en "vis støbning", som de studerende udtrykker det. Samtidig er det krævende for vejlederen. I tråd med et nyligt amerikansk studie (Hall et al., 2018) påpeger vores fund, at der kan være en mulig skævvridning i, hvilke vejledere der har overskud til at praktisere forskningssamarbejde og sampublicering med studerende. Dels er det en meget ressourcekrævende opgave i form af tid og eksterne forskningsmidler, dels kræver det solid erfaring med artikelpublicering. Samlet vidner det om, at modellen ikke kun appellerer til elitestuderende, men måske også til eliteforskere?

Endelig bidrager vores studie med nye perspektiver på det klassiske dilemma mellem lærings- og investorrationalet, idet høje krav til studerendes arbejdsindsats og ansvar og stort læringsudbytte til en vis grad kan retfærdiggøre en høj grad af vejlederstøtte og styring.

\section{Anerkendelse}

Tak til de fire specialestuderende, som stillede op til interviews, og som åbent og nuanceret delte deres oplevelser. Også stor tak til studentermedhjælper Mikkel Lemme Jakobsen, der stod for en stor del af kode- og analysearbejdet.

\section{Referencer}

Almutrafi, F. (2019). The What, Why and How of Conducting Focus-Group Research. International Journal of Language and Linguistics, 7(5), 235-239.

Barnes, G.P. \& Cheng, M. (2019).Working independently on the dissertation proposal: experiences of international Master's students. Journal of Further and Higher Education, 43(8), 1120-1132

Bastalich, W. (2015). Content and context in knowledge production: a critical review of doctoral supervision literature. Studies in Higher Education, 42(7), 1145-1157.

Becher, T. (1994). The significance of disciplinary differences. Studies in Higher Education, 19(2),151-161.

Biglan, A. (1973). Relationships between subject matter characteristics and the structure and output of university departments. Journal of Applied Psychology, 57(3), 204-213.

Boehe, D.K. (2016) Supervisory styles: a contingency framework, Studies in Higher Education, 41(3), 399-414.

Bovill, C., Cook-Sather, A., Felten, P., Millard, L. \& Moore-Cherry, N. (2016). Addressing potential challenges in 
co-creating learning and teaching: overcoming resistance, navigating institutional norms and ensuring inclusivity in student-staff partnerships. Higher Education 71(2), 195-208.

Biggs, J. (2012) What the student does: teaching for enhanced learning. Higher Education Research \& Development, 31(1), 39-55.

Burks, R. L. \& Chumchal, M. M. (2009). To co-author or not to co-author: how to write, publish, and negotiate issues of authorship with undergraduate research students. Science Signaling, 2(94), 1-7.

Christensen, M. \& Tegtmejer, T. (2015). Forskningsåret som karriereplatform. Center for Sundhedsvidenskabelige Uddannelser, Aarhus Universitet. https://pure.au.dk/portal/files/94020047/CESU_Forsknings ret som karriereplatform.pdf

Cook-Sather, A., Bovill, C. \& Felten, P. (2014). Engaging students as partners in teaching and learning: A guide for faculty. Jossey-Bass.

Deuchar, R. (2008). Facilitator, director or critical friend?: contradiction and congruence in doctoral supervision styles. Teaching in Higher Education, 13(4), 489-500

de Kleijn, R., Meijer, P.C., Brekelmans, M. \& Pilot, A. (2013). Curricular Goals and Personal Goals in Master's Thesis Projects: Dutch Student-Supervisor Dyads. International Journal of Higher Education 2(1): 1-11.

Eagan, M. K., Sharkness, J., Hurtado, S., Mosqueda, C. M. \& Chang, M. J. (2011). Engaging Undergraduates in Science Research: Not Just About Faculty Willingness. Research in higher education, 52(2), 151-177.

Ginn, F. (2014). "Being Like a Researcher": Supervising Masters Dissertations in a Neoliberalizing University. Journal of Geography in Higher Education, 38(1), 106-118.

Gravett, K., Kinchin, I.M. \& Winstone, N.E. (2020). "More than customers": conceptions of students as partners held by students, staff, and institutional leaders. Studies in Higher Education, 45(12), 2574-2587.

Greenbank, P. \& Penketh, C. (2009). Student Autonomy and Reflections on Researching and Writing the Undergraduate Dissertation. Journal of Further and Higher Education, 33(4), 463-472.

Hall, E.E., Walkington, H., Shanahan, J.O., Ackley, E. \& Stewart, K. A (2018). Mentor perspectives on the place of undergraduate research mentoring in academic identity and career development: an analysis of award winning mentors, International Journal for Academic Development, 23(1), 15-27.

Hansen, A., Hansen, M. \& Krogh, A. (2020). Muligheder og dilemmaer i forskningssamarbejder mellem undervisere og studerende. Dansk Universitetspædagogisk Tidsskrift, 16(29), 2-13.

Healey, M., Flint, A. \& Harrington, K. (2014). Engagement through partnership: students as partners in learning and teaching in higher education. The Higher Education Academy.

https://www.heacademy.ac.uk/sites/default/files/resources/engagement through partnership.pdf

Hill, J., Healey, R.L., West, H. \& Déry, C. (2019). Pedagogic partnership in higher education: encountering emotion in learning and enhancing student wellbeing. Journal of Geography in Higher Education, DOI: 10.1080/03098265.2019.1661366. 
Jenkins, A. and Healey, M. (2012). Research-led or research-based undergraduate curricula. In: L. Hunt \& D. Chalmers (Eds.), University teaching in focus: a learning centred approach (128-44). Acer.

Jeppsson, F. \& Haglund, J. (2019). Sampublicering med studenter - ett sätt att stärka forskningsanknytningen i lärarutbildningen. Högre Utbildning, 9(1), 98-111.

Jung, J. (2019). Learning experience and academic identity building by master's students in Hong Kong, Studies in Higher Education, DOI: 10.1080/03075079.2019.1652811

Kiley, M. \& Cumming, J. (2015). Enhanced learning pathways and support for coursework master's students: challenges and opportunities. Higher Education Research \& Development, 34(1), 105-116.

Kuh, G. (2008). High-Impact Educational Practices: What They Are, Who Has Access to Them, and Why They Matter. Association of American Colleges \& Universities. https://provost.tufts.edu/celt/files/High-Impact-EdPractices1.pdf

Kuh, G. \& O'Donnell, K. (2013). Ensuring quality and taking high-impact practices to scale. Association of American Colleges and Universities. https://www.aacu.org/publications-research/publications/ensuringquality-and-taking-high-impact-practices-scale

Laursen, S.L., Hunter, A-B., Seymour, E., Thiry, H. and Melton, G. (2010). Undergraduate research in the sciences: Doing real science. Jossey-Bass.

Lee, A. \& McKenzie, J. (2011). Evaluating doctoral supervision: tensions in eliciting students' perspectives. Innovations in Education and Teaching International, 48(1), 69-78

Levy, P. (2011). Embedding inquiry and research into mainstream higher education: A UK perspective. Council on Undergraduate Research Quarterly, 32(1), 36-42.

Madsen, L.M. \& Winsløw, C. (2009). Relations between teaching and research in physical geography and mathematics at research-intensive universities. International Journal of Science and Mathemathics Education 7 , 741-763.

Magnusson, J. \& Zackariasson, M. (2019) Student independence in undergraduate projects: different understandings in different academic contexts. Journal of Further and Higher Education, 43(10), 1404-1419.

Malcolm, M. (2012). Examining the Implications of Learner and Supervisor Perceptions of Undergraduate Dissertation Research in Business and Management. Teaching in Higher Education, 17(5), 565-576.

Miles, M.B., Huberman, A.M. \& Saldana, J. (2014). Qualitative Data Analysis: A Methods Sourcebook and The Coding Manual for Qualitative Researchers. SAGE.

Moore, J.L. \& Felten, P. (2018). Academic development in support of mentored undergraduate research and inquiry. International Journal for Academic Development, 23(1), 1-5.

Osborn, J. M. \& Karukstis, K. K. (2009). The benefits of undergraduate research, scholarship, and creative activity. In: M. Boyd and J. Wesemann (Eds.), Broadening Participation in Undergraduate Research: Fostering Excellence and Enhancing the Impact (s.41-53). Council on Undergraduate Research, Washington, DC. 
Ramian, K. (2012). Casestudiet i praksis. Hans Reitzels Forlag

Rienecker, L., Wichmann-Hansen, G. \& Jørgensen, P.S. (2019) God vejledning - af specialer, bacheloropgaver og projekter. Forlaget Samfundslitteratur.

Shaw, K., Holbrook, A. \& Bourke, S. (2013). Student experience of final year undergraduate research projects: an exploration of "research preparedness". Studies in Higher Education, 38(5), 711-727

Simpson, T. E., Safa, M., Sokolova, A. \& Latiolais, P. G. (2019). Career Readiness and Employment Expectations: Interdisciplinary Freshman Experience. Journal of Business and Management Sciences, 7(3), 121-130.

Spronken-Smith, R. A., Brodeur, J. J., Kajaks, T., Luck, M., Myatt, P., Verburgh, A., Walkington, H. and Wuetherick, B. (2013). Completing the research cycle: A framework for promoting dissemination of undergraduate research and inquiry. Teaching and Learning Inquiry, 1(2), 105-18.

Thiry, H., Weston, T.J., Laursen, S.L. \& Hunter, A-B. (2012). The Benefits of Multi-Year Research Experiences: Differences in Novice and Experienced Students' Reported Gains from Undergraduate Research. CBE-Life Sciences Education, 11, 260-272. https://doi.org/10.1187/cbe.11-11-0098

Todd, M., Bannister, P. and Clegg, S. (2004). Independent Inquiry and the Undergraduate Dissertation: Perceptions and Experiences of Final-Year Social Science Students. Assessment \& Evaluation in Higher Education, 29(3), 335-355.

Todd, M.J., Smith, K. \& Bannister, P. (2006). Supervising a social science undergraduate dissertation: staff experiences and perceptions. Teaching in Higher Education 11(2), 161-173.

Uddannelses- og Forskningsministeriet. (2020). Forskningsbaseret uddannelse. Undersøgelse af forskningselementet i udvalgte kandidatuddannelser. Styrelsen for Forskning og Uddannelse. https://ufm.dk/publikationer/2020/filer/forskningsbaseret-uddannelse publikation korrekturlaest 230620.pdf

Wulf-Andersen T., Hjort-Madsen P., Mogensen K.H. (2015). Research Learning - How Students and Researchers Learn from Collaborative Research. In: A. Andersen \& S. Heilesen (Eds), The Roskilde Model: Problem-Oriented Learning and Project Work. Innovation and Change in Professional Education (s. 211-231). Springer. DOI: 10.1007/978-3-319-09716-9_14

Yin, R. K. (2009). Case study research: Design and methods (4th Ed.). SAGE. 


\section{Betingelser for brug af denne artikel}

Denne artikel er omfattet af ophavsretsloven, og der må citeres fra den.

Følgende betingelser skal dog være opfyldt:

- Citatet skal være i overensstemmelse med "god skik"

- Der må kun citeres „i det omfang, som betinges af formålet"

- Ophavsmanden til teksten skal krediteres, og kilden skal angives ift. ovenstående bibliografiske oplysninger

\section{(C) Copyright}

DUT og artiklens forfatter
Udgivet af

Dansk Universitetspædagogisk Netværk

\footnotetext{
' De studerende kendte det traditionelle speciale dels fra deres andre medstuderende, dels fra vejlederens præsentation på Oktoberdagen
} 